\title{
Hybrid Jaringan Saraf Tiruan Backpropagation dengan Firefly Algorithm dan Simulated Annealing untuk Peramalan Curah Hujan di Surabaya
}

\author{
Dicky Zulfikar Zurkarnain', Auli Damayanti ${ }^{2, *}$ \& Edi Winarko ${ }^{3}$ \\ ${ }^{1,2,3}$ Departemen Matematika Fakultas Sains dan Teknologi Universitas Airlangga, Surabaya, \\ Indonesia
}

"Corresponding author Email: auli-d@fst.unair.ac.id

\begin{abstract}
Abstrak. Indonesia mempunyai berbagai jenis iklim. Salah satu parameter iklim adalah curah hujan. Curahhujan yang dapat menjadi sumber bencana adalah curah hujan ekstrem, yaitu kondisi curah hujan yang cukup tinggi/rendah dari rata-rata kondisi normalnya. Informasi tentang peramalan curah hujan sangat berguna khususnya bagi pemerintah kota Surabaya dalam mengantisipasi kemungkinan kejadian-kejadianatau bencana yang diakibatkan oleh curah hujan ekstrem seperti, kekeringan, banjir, pohon tumbang, rusaknya fasilitas umum, dll. Tujuan dari penulisan skripsi ini adalah untuk mendapatkan nilai peramalan curah hujan di Surabaya pada bulan yang akan datang menggunakan Hybrid Jaringan Saraf Tiruan Backpropagation dengan Firefly Algorithm dan Simulated Annealing. Proses diawali dengan input dan normalisasi data, kemudian dilanjutkan dengan proses pelatihan untuk mencari bobot dan bias yang optimal. Setelah diperoleh bobot dan bias yang optimal, kemudian melakukan uji validasi, dan dilanjutkandengan proses peramalan. Pada proses peramalan curah hujan, data yang digunakan sebanyak 120 data curah hujan bulanan dari bulan Januari 2008 hingga bulan Desember 2017 dengan ketentuan $80 \%$ data untuk pelatihan dan $20 \%$ data untuk uji validasi. Data yang digunakan, selanjutnya dilatih kemudian dicarinilai Mean Square Error (MSE) dan bobot yang optimal. Bobot optimal yang diperoleh, selanjutnya diuji dengan uji validasi untuk mengetahui seberapa baik pola yang dikenali. Berdasarkan implementasi pada data curah hujan tersebut, diperoleh nilai MSE hasil pelatihan sebesar 0.0395384228 dan nilai selisih rata-rata sebesar 3,75382. Sedangkan hasil peramalan untuk 3 bulan berikutnya yaitu bulan Januari hinggaMaret 2018 berturut-turut adalah $6.1451,8.5459$, dan 7.7391 .
\end{abstract}

Keywords: Jaringan Saraf Tiruan Backpropagation, Firefly Algorithm, Simulated Annealing, Peramalan, Curah Hujan.

\section{Pendahuluan}

Indonesia mempunyai berbagai jenis iklim. Secara geografis Indonesia terletak di antara SamudraPasifik dan Samudra Hindia, antara benua Asia dan benua Australia, dan pada pertemuan dua rangkaian pegunungan, yaitu Sirkum Pasifik dan Sirkum Mediterrania. Sebagian besar wilayah Indonesia merupakan lautan, sedangkan wilayah daratan pada umumnya memiliki permukaan yang bergunung-gunung. Kondisi wilayah tersebutlah yang menyebabkan adanya keragaman iklim di wilayah Indonesia. 
Salah satu parameter iklim adalah curah hujan. Curah hujan menjadi sumber daya alam yang amat dibutuhkan, juga dapat menjadi sumber bencana. Curah hujan yang dapat menjadi sumber bencana adalah curah hujan ekstrem, yaitu kondisi curah hujan yang cukup tinggi/rendah dari rata-rata kondisi normalnya. Curah hujan ekstrem biasanya disebabkan oleh fenomena siklus El-Nino dan La-Nina. El-Nino menyebabkab kekeringan karena curah hujan sangat rendah, dan La-Nina menyebabkan banjir karena curahhujan sangat tinggi [1].

Surabaya adalah ibukota provinsi Jawa Timur dengan jumlah populasi penduduk yang padat. Informasi tentang peramalan curah hujan sangat berguna khususnya bagi pemerintah kota Surabaya dalam mengantisipasi kemungkinan kejadian-kejadian atau bencana yang diakibatkan oleh curah hujan ekstrem seperti, kekeringan, banjir, pohon tumbang, rusaknya fasilitas umum, dll. Di kota Surabaya sendiri, banjir masih sering terjadi jika ada hujan dengan intensitas tinggi. Menurut [2], Surabaya adalah salah satu kota dengan persoalan banjir yang besar karena selalu mengalami banjir setiap tahunnya dengankerugian yang cukup besar. Kerugian dan kerusakan akibat banjir adalah sebesar dua pertiga dari semua bencana alam yang terjadi.

Jaringan saraf tiruan (Artificial Neural Network) adalah salah satu cabang dari ilmu kecerdasan buatan (Artificial Intelligent) yang sering digunakan untuk masalah pengelompokkan dan pengenalan suatu pola. Karena jaringan saraf tiruan dirancang seperti cara kerja otak manusia. Sehingga jaringan saraf tiruanlebih unggul dibandingkan dengan algoritma konvensional lainnya khususnya untuk pengelompokkan dan pengenalan pola. Jaringan saraf tiruan juga menggunakan proses pembelajaran atau pelatihan dalam prosesnya. Proses pelatihan data ini bertujuan untuk memperoleh bobot dan bias yang optimal yang sesuaidengan pola data yang dilatih [3]. Jaringan saraf tiruan mempunyai kemampuan belajar yang baik dan dapat dengan mudah beradaptasi dengan lingkungannya. Jaringan saraf tiruan dapat mengenali pola dari berbagai macam distribusi data termasuk data yang tidak teratur dan tidak berkaitan [4].

Jaringan saraf tiruan Backpropagation adalah salah satu diantara banyak metodologi yang sangatluas digunakan untuk menyelesaikan masalah pengenalan pola karakter. Struktur Jaringan saraf tiruan Backpropagation cukup sederhana, algoritmanya matang dan dapat diaplikasikan di berbagai bidang. Backpropagation adalah metode gradient descent yang mana persentase kesalahan dihitung denganmemperhatikan bobot yang diberikan pada input awal dengan perambatan balik dari output layer menuju hidden layer dan selanjutnya ke input layer [5].

Jaringan Saraf Tiruan Bacpropagation bekerja dengan baik pada permasalahan pelatihan sederhana. Jika kompleksitas permasalahan meningkat, maka daya kerja dari backpropagation ini turun drastis kedalam minimum lokal, dan proses pelatihannya sangat lambat karena proses pencarian bobot. Untuk mengatasi keterbatasan ini, 
beberapa pengombinasian Jaringan saraf tiruan Backpropagation telah dikembangkan, yaitu mengombinasikan dengan algoritma metaheuristik seperti Particle Swarm Optimization (PSO), Firefly Algorithm (FA), dan Genetic Algorithm (GA) yang dapat dimasukkan ketika proses pelatihan jaringan [5].

Algoritma Kunang-kunang (Firefly Algorithm) adalah algoritma metaheuristik yang terinspirasi dari kecerdasan koloni hewan (Swarm Intelligence) yaitu perilaku berkedipnya cahaya kunang-kunang dancara komunikasi kunang-kunang melalui cahaya yang dimilikinya [6]. Algoritma kunang- kunang mempunyai kelebihan yaitu tingginya tingkat konvergensi dan masing-masing individu firefly memperoleh optimum global dengan jumlah iterasi yang sedikit [5].

Simulated Annealing (SA) adalah salah satu algoritma untuk optimasi yang terinspirasi dari bidang metalurgi annealing, yaitu suatu teknik yang digunakan dalam mempelajari proses pembentukan kristal dalam suatu materi. Agar dapat terbentuk susunan kristal yang sempurna, diperlukan pemanasan sampai tingkat tertentu, kemudian dilanjutkan dengan pendinginan yang perlahan-lahan dan terkendali dari materi tersebut. Algoritma ini dapat digunakan untuk mencari pendekatan terhadap solusi optimum lokal dari suatu permasalahan [7]. Berbeda dari banyak metode yangada, algoritma Simulated Annealing tidak mudah terjebak di minimum lokal. Kemampuan algoritma Simulated Annealing dalam menyelesaikan permasalahan optimasi yang kompleks sangat bagus [8].

Berdasarkan penelitian [5], untuk meningkatkan hasil solusi dari jaringan saraf tiruan dengan proses pelatihan Backpropagation, digunakan algoritma optimasi untuk menentukan bobot optimal dalam tahap pembelajaran. Dalam [9] proses optimasi bobot jaringan saraf tiruan Backpropagation menggunakan Firefly Algorithm untuk memperoleh bobot optimal dibutuhkan iterasi lebih sedikit dibandingkan dengan mengguakan Genetic Algorithm (GA). Dalam [8] proses pelatihan jaringan saraf tiruan dengan algoritma optimasi telah menunjukkan bahwa metode tersebut menjadi pendekatan yang efektif untuk mencari solusi optimal. Pada kombinasi jaringan saraf tiruan dengan Simulated Annealing (SA), Simulated Annealing digunakan pada proses pelatihan pada jaringan saraf tiruan. Oleh karena itu, pada penelitian kali ini, Jaringan saraf tiruan Bacpropagation digunakan untuk peramalan curah hujan di Surabaya dan Firefly Algorithm serta Simulated Annealing digunakan untuk optimasi bobotnya. Dengan menggunakan Jaringan saraf tiruan Backpropagation untuk peramalan diharapkan dapat membantu pemerintah kota Surabaya dalam pengambilan keputusan serta mengambil langkah antisipatif sebelum datangnya curah hujan ekstrem, sehingga bisa mengurangi dampak dan kerugian yang diakibatkan oleh curah hujan ekstrem.

Dengan adanya kekurangan dan kelebihan yang ada pada jaringan saraf tiruan dan firefly algorithmini, maka menarik untuk dilakukan pengombinasian (hybrid) jaringan saraf tiruan metode extreme learningmachine dengan firefly algorithm pada proses pelatihan 
jaringan, agar pencarian bobot dan bias dalam proses pelatihannya menjadi lebih cepat. Dengan demikian diharapkan setelah proses pelatihan berlangsung, diperoleh solusi yang lebih baik sehingga akurat untuk memprediksi nilai tukar rupiah terhadap dolar Amerika Serikat.

\section{Landasan Teori}

Beberapa penjelasan mengenai teori yang berkaitan dengan penelitian dijelaskan pada bagian ini.

\section{A. Curah Hujan}

Curah hujan dapat diartikan sebagai ketinggian air yang terkumpul dalam tempat yang datar, tidak menguap, tidak meresap, dan tidak mengalir. Untuk mengukur curah hujan, digunakan alat yang disebut Observarium dan umumnya curah hujan dinyatakan dalam milimeter. Curah hujan satu milimeter artinya pada luasan satu meter persegi dalam tempat yang datar tertampung air setinggi satu milimeter atau tertampung air sebanyak satu liter ( 1 inchi=25,4 mm). jika curah hujan dihitung pada rentang kumulatif tertentu maka disebut curah hujan kumulatif dan perbandingan antara jumlah curah hujan selama waktu tertentu yang diterapkan (satu periode musim kemarau atau musim hujan) dengan jumlah curah hujan normalnya (rata-rata selama 30 tahun) disebut sebagai sifat hujan [10]. Sifat hujan berdasarkan BMKG dibagi menjadi tiga sifat, yaitu atas normal, normal dan bawah normal. Hujan dikatakan normal apabila tinggi hujan yang terjadi pada suatu musim berada pada selang antara $85 \%$ samapai $115 \%$ dari nilai ratarata hujan jangka panjang. Dikatakan bawah normal apabila tinggihujan kurang dari 85 $\%$ dari nilai rata-rata dan diatas normal apabila tinggi hujan lebih besar dari $115 \%$ dari nilai rata-rata. Pada saat fenomena La-Nina berlansung, biasanya sifat hujan di Indonesia khususnya yang memiliki pola hujan monsoon akan dia atas nomal, sebaliknya kalau fenomena El-Nino yang berlangsung sifat hujan akan dibawah normal.

B. Jaringan Saraf Tiruan Backpropagation

Jaringan saraf backpropagation merupakan jaringan saraf yang menggunakan arsitektur multilayer. Dalam jaringan, selain terdapat unit-unit input, unit-unit tersembunyi (hidden) dan output jugaterdapat bias yang diberikan pada unit-unit tersembunyi dan output. Unit input akan dilambangkan dengan $\mathrm{X}$, unit hidden dilambangkan dengan $\mathrm{Z}$, dan unit output dilambangkan dengan Y. Sedangkan, untuk bobotantara X dan Z dilambangkan dengan $\mathrm{V}$ dan bobot antara $\mathrm{Z}$ dan $\mathrm{Y}$ dilambangkan dengan $\mathrm{w}$. Untuk bias, biasanya dipakai indeks indeks $\mathrm{v}_{01}$ dan $\mathrm{w}_{01}$. Pada intinya, pelatihan dengan metode backpropagation terdiri atas tiga langkah, yaitu :

1. Umpan maju, data dimasukkan ke input jaringan (feedforward). Saat umpan maju, setiap unit input $\left(X_{i}\right)$ akan menerima sinyal input dan akan menyebarkan sinyal 
tersebut pada tiap unit hidden $\left(Z_{j}\right)$. Setiap unit hidden kemudian akan menghitung aktivasinya dan mengirim sinyal $\left(z_{j}\right)$ ke tiap unit output. Kemudian, setiap unit output $\left(Y_{k}\right)$ juga akan menghitung aktivasinya $\left(y_{k}\right)$ untuk menghasilkan respon terhadap input yang diberikan jaringan.

2. Propogasi error, perhitungan dan propagasi balik dari error yang bersangkutan. Saat proses pelatihan, setiap unit output membandingkan aktivasinya $\left(y_{k}\right)$ dengan nilai target untuk menentukan besarnya error. Berdasarkan error tersebut, dihitung factor $\delta_{k}$. Faktor $\delta Y_{k}$ digunakan untuk mendistribusikan error dan output kembali ke layer sebelumnya. Dengan cara yang sama, faktor $\delta Z_{k}$ juga dihitung pada unit hidden $Z_{j}$. Faktor $\delta_{k}$ digunakan untuk memperbaharui bobot antara hidden layer dan input layer.

3. Pembaharuan bobot dan bias. Setelah semua faktor $\delta$ ditentukan, bobot untuk semua layer diperbaharui secara bersamaan. Pembaharuan bobot $w_{j k}$ (dari unit hidden $Z_{j}$ ke unit output $Y_{k}$ ) dilakukan berdasarkan faktor $\delta Y_{k}$ dan aktivasi $Z_{j}$ dari unit hidden $Z_{j}$. Sedangkan, pembaharuan bobot $v_{i j}$ (dari unit input $X_{i}$ ke unit hidden $Z_{j}$ ) dilakukan berdasarkan faktor $\delta Z_{j}$, dan aktivasi $x_{i}$, dari input.

Pada tiap langkah yang dijalani, neuron-neuron diaktifkan dengan menggunakan fungsi aktivasi sigmoid biner. Fungsi aktivasi tersebut digunakan pada proses input ke hidden maupun dari hidden ke output [3].

C. Firefly Algorithm

Menurut [6], terdapat dua hal yang berkaitan dan sangat penting dalam Firefly Algorithm yatu intensitas cahaya dan fungsi keatraktifan. Diasumsikan bahwa keatraktifan dipengaruhi tingkat intensitas cahaya. Dalam kasus optimasi maksimum, tingkat itensitas cahaya pada sebuah firefly $x$ dapat dilihat sebagai,

$$
I(x) \approx f(x)
$$

dengan nilai $I$ adalah tingkat intensitas cahaya pada firefly $x$ yang sebanding dengan solusi fungsi tujuan permasalahan yang akan dicari $f(x)$. Nilai keatraktifan firefly $(\beta)$ adalah relatif, karena dipengaruhi besar kecilnya intensitas cahaya. Sehingga hasil penilaian akan berbeda juga tergantung dari jarak antar firefly $\left(r_{i j}\right)$. Selain itu, intensitas cahaya akan menurun dilihat dari sumbernya dikarenakan terserap oleh media, contohnya udara. Fungsi keatraktifan $((r))$ diberikan sebagai berikut:

$$
\beta(r)=\beta_{0} e^{-\gamma r^{2}}
$$

dengan $\beta_{0}$ adalah nilai keatraktifan firefly awal, $\gamma$ adalah koefisien penyerapan cahaya, $r$ adalah jarak antar firefly. Seberapa besar suatu firefly dapat melihat cahaya firefly yang lain dipengaruhi oleh faktor jarak. Semakin jauh jarak antar firefly semakin redup cahaya 
dari firefly yang berkedip. Jarak antara firefly $i$ dan $j$ pada posisi $x$ masing-masing adalah $x_{i}$ dan $x_{j}$ yang dapat dihitung menggunakan rumus sebagai berikut:

$$
r_{i j}=\left\|x_{i}-x_{j}\right\|=\sqrt{\sum_{k=1}^{d}\left(x_{i}^{k}-x_{j}^{k}\right)^{2}}
$$

dengan $d$ adalah jumlah komponen tiap individu firefly, $x_{i}^{k}$ adalah komponen ke- $k$ dari firefly ke- $i\left(x_{i}\right)$ dan $x_{j}^{k}$ adalah komponen ke- $k$ dari firefly ke-j $\left(x_{\mathrm{j}}\right)$. Pergerakan dari firefly $i$ yang bergerak menuju firefly $j$ yang mempunyaiintensitas cahaya yang lebih cerah dapat dilihat dari persamaan berikut:

$$
x_{i}^{\text {baru }}=x_{i}+\beta_{0} e^{-\gamma r_{i j}^{2}}\left(x_{j}-x_{i}\right)+\alpha(\text { rand }-0.5)
$$

dengan $\beta_{0} e^{-\gamma r_{i j}^{2}}\left(x_{j}-x_{i}\right)$ adalah perpindahan firefly yang terjadi karena adanya daya tarik (keatraktifan firefly) dan $\alpha$ (rand - 0,5) adalah pergerakan random firefly dengan $\alpha$ adalah koefisien parameter random dan rand adalah bilangan random berdistribusi uniform pada interval [0,1]. Pada sebagian besar implementasi, digunakan $\beta_{0}=1, \alpha \in$ $[0,1]$ dan $\gamma \in[0, \infty)$.

Langkah-langkah dasar dari Firefly Algorithm untuk menyelesaikan suatupermasalahan sebagai berikut:

1. Inisialisasi parameter Firefly Algorithm, yaitu koefisien penyerapan cahaya $(\gamma)$, banyaknya firefly $(m)$, keatraktifan awal $\left(\beta_{0}\right)$, koefisien parameter random $(\alpha)$.

2. Mendefinisikan fungsi objektif $(x)$ dari permasalahan yang akan diselesaikan dengan FireflyAlgorithm.

3. Membangkitkan secara random populasi awal dengan generate firefly sebanyak $m$.

4. Menentukan intensitas cahaya tiap firefly $(x)$ berdasarkan nilai fungsi tujuan $(x)$.

5. Membandingkan intensitas cahaya masing-masing firefly dengan firefly lainnya. Jika intensitascahaya firefly $i$ lebih rendah dari firefly $j$ maka terjadi pergerakan dari firefly $i$ ke firefly $j$.

6. Menentukan G-best. Untuk iterasi pertama, firefly terbaik (firefly dengan intensitas cahayaterbesar) adalah G-best.

7. Melakukan proses di atas sampai batas iterasi dipenuhi.

D. Simulated Annealing

Nama dan inspirasi dari Simulated Annealing berasal dari bidang metalurgi yaitu Annealing. Annealing adalah suatu teknik yang digunakan dalam mempelajari proses pembentukan kristal dalam suatu materi. Agar dapat terbentuk susunan kristal yang sempurna, diperlukan pemanasan sampai tingkat tertentu, kemudian dilanjutkan dengan pendinginan yang perlahan-lahan dan terkendali dari materi tersebut. Pemanasan materi 
diawal proses annealing memberikan kesempatan pada atom-atom dalam materi tersebut untuk bergerak secara bebas. Proses pendinginan yang perlahanlahan memungkinkan atom-atom dari materi tersebut untuk menemukan tempat yang optimum, yaitu kondisi dimana energi internal yang dibutuhkan atom itu untuk mempertahankan posisinya adalah minimum.

Prosedur Simulated Annealing secara garis besar dapat dijabarkan sebagai berikut [7]:

1. Inisialisai temperatur awal $T_{\text {sekarang }}$.

2. Inisialisasi populasi awal $v_{i}$.

3. Evaluasi populasi awal sebagai solusi sementara $f\left(v_{i}\right)$.

4. Modifikasi populasi awal $v_{m}$ dan evaluasi kembali sebagai solusi baru $f\left(v_{m}\right)$.

5. Jika $f\left(v_{m}\right) \leq f\left(v_{i}\right)$ maka solusi sementara sama dengan solusi baru. Jika tidak maka dibangkitkan dengan acak bilangan real $r$ pada interval $[0,1]$. Hitung probabilitas $p=e^{\frac{\Delta f}{T}}$ dengan $\Delta f$ merupakan selisih dari $f\left(v_{i}\right)$ dan $f\left(v_{m}\right)$, Sedangkan $T$ adalah suhu saat ini. Jika $p>r$ maka solusi baru tetap diterima sebagai solusi sementara.

6. Jika sudah mencapai $T_{i}<T_{a k h i r}$, maka algoritma berhenti. Jika tidak, hitung perubahan temperatur $T_{i}=t T_{\text {sekarang }}$ dengan $0<t<1$ dan kembali ke Langkah 4.

\section{Metode Penelitian}

Langkah-langkah yang digunakan dalam penelitian ini adalah sebagai berikut:

1. Melakukan studi pustaka mengenai curah hujan, peramalan, firefly algorithm (FA), algoritma simulated annealing (SA) dan jaringan saraf tiruan backpropagation (JSTB).

2. Melakukan normalisasi data. Proses normalisasi, dilakukan pada data yang akan digunakan dan dirubah pada interval $[0,1]$. Rumus normalisasi yang digunakan untuk mengubah data ke interval $[0,1]$ adalah :

$$
x=\frac{0,8 \times\left(x_{d}-\min \left(x_{d}\right)\right)}{\left(\max \left(x_{d}\right)-\min \left(x_{d}\right)\right)}+0.1
$$

dengan :

$x_{d}=$ data asli yang belum dilakukan proses normalisasi

$\min \left(x_{d}\right)=$ nilai minimum pada seluruh data

$\max \left(x_{d}\right)=$ nilai maksimum pada seluruh data

3. Melakukan pembagian data menjadi data pelatihan dan data validasi dengan komposisi $80 \%$ dari total data sebagai data pelatihan $20 \%$ dari total data sebagai 
data validasi.

4. Merancang data yang akan menjadi input. Jumlah neuron input yang digunakan adalah sebanyak 3 unit yang artinya mewakili data sebanyak 3 bulan. Sedangkan target output yang digunakan adalah data bulan ke-4 dan seterusnya. Berikut rancangan data yang nantinya akan digunakan disajikan pada Tabel 1.

Tabel 1 Rancangan data

\begin{tabular}{|c|c|c|c|c|}
\hline \multirow{2}{*}{$\begin{array}{c}\text { Pola } \\
\text { ke- }\end{array}$} & \multicolumn{3}{|c|}{ Data Input } & \multirow{2}{*}{ Target } \\
\cline { 2 - 4 } & $\mathrm{x} 1$ & $\mathrm{x} 2$ & $\mathrm{x} 3$ & \\
\hline 1 & Bulan ke-1 & Bulan ke-2 & Bulan ke-3 & Bulan ke-4 \\
\hline 2 & Bulan ke-2 & Bulan ke-3 & Bulan ke-4 & Bulan ke-5 \\
\hline 3 & Bulan ke-3 & Bulan ke-4 & Bulan ke-5 & Bulan ke-6 \\
\hline$\cdot$ & $\cdot$ & $\cdot$ & $\cdot$ & $\cdot$ \\
$\cdot$ & $\cdot$ & $\cdot$ & $\cdot$ & $\cdot$ \\
$\cdot$ & $\cdot$ & $\cdot$ & $\cdot$ & $\cdot$ \\
\hline$n-3$ & Bulan ke- $(n-3)$ & Bulan ke-(n-2) & Bulan ke- $(n-1)$ & Bulan ke- $n$ \\
\hline
\end{tabular}

5. Merancangan arsitektur jaringan saraf tiruan dengan metode Backpropagation. Pada penelitian ini, jaringan hanya terdiri dari 3 layer, yaitu sebuah input layer, sebuah hidden layer, dan sebuah output layer. Rancangan jumlah unit pada tiap layer:

a. Pada input layer terdapat jumlah neuron sebanyak 3 unit, yaitu data setiap 3 bulan.

b. Pada hidden layer terdapat jumlah neuron sebanyak 3 unit.

c. Pada output layer terdapat jumlah neuron sebanyak 1 unit

d. Fungsi aktivasi yang digunakan adalah fungsi aktivasi sigmoid biner.

6. Menerapkan Hybrid Jaringan Saraf Tiruan Backpropagation dengan Firefly Algorithm dan Simulated Annealing pada proses pelatihan data dengan langkahlangkah sebagai berikut :

a. Mempersiapkan data yang akan digunakan untuk pelatihan.

b. Menentukan banyaknya populasi firefly $(n)$, keatraktifan awal $\left(\beta_{0}\right)$, koefisien penyerapan udara $(\gamma)$, koefisien nilai random $(\alpha)$, target error (maks_error), maksismum iterasi (maks_iterasi), suhu awal $\left(T_{0}\right)$, suhu akhir $\left(T_{a}\right)$, dan koefisien penurunan suhu $(t)$.

c. Membangkitkan populasi awal pada FA dengan cara membangkitkan bilangan real secara random pada interval $[0,1]$ sebanyak $n$ populasi. Jumlah komponen tiap-tiap individu firefly sebanyak 16 unit. Populasi yang dibangkitkan merupakan bobot dan bias yang akan digunakan dalam pelatihan JSTB. 
d. Konversi individu firefly dalam FA menjadi bobot dan bias dalam JST.

e. Melakukan proses pelatihan Jaringan Saraf Tiruan Backpropagation pada bobot dan bias masing-masing individu firefly. Selanjutnya didapatkan nilai MSE untuk masing-masing individu firefly.

f. Menghitung nilai intensitas cahaya dari nilai MSE yang diperoleh tiap individu firefly menggunakan rumus berikut:

$$
I(x)=\frac{1}{1+M S E}
$$

g. Membandingkan intensitas cahaya firefly ke- $i$ dengan firefly ke- $j$. Jika intensitas cahaya firefly ke- $i$ lebih besar dari firefly ke- $j$, ulangi langkah ini dengan $j=j+1$. Jika intensitas cahaya firefly ke- $i$ lebih kecil dari firefly ke$j$, hitung jarak antara firefly ke- $i$ dan firefly ke- $j$, hitung nilai keaktraktifan firefly dan lakukan pergerakan dari fiefly ke- $i$ menuju firefly ke-j.

h. Mengevaluasi fungsi tujuan (MSE) dan intensitas cahaya setelah pergerakan seperti Langkah6.e-f.

i. Ulangi langkah 6.g dengan $i=i+1$ sampai seluruh firefly dibandingkan.

j. Tentukan firefly terburuk sebagai solusi awal dalam proses Simmulated Annealing dan hitung cost dari solusi awal tersebut menggunakan rumus :

$$
C(x)=\frac{1}{I(x)}
$$

k. Melakukan proses Simulated Annealing dengan langkah-langkah sebagai berikut :

i. Membangkitkan solusi baru, yaitu dengan memodifikasi firefly terburuk menggunakan mutasi.

ii. Mengevaluasi solusi baru, proses evaluasi dilakukan seperti Langkah 6.e-f, dengan intensitas cahaya yang didapat kemudian ditransformasikan menjadi cost untuk solusibaru.

iii. Hitung selisih cost lama dan cost baru $(\Delta f)$.

iv. Jika $\Delta f$ negatif maka solusi baru diterima, jika tidak maka random bilangan real $r \in[0,1]$, hitung probabilitas penerimaan, apabila $r<p$ maka solusi baru diterima, jika tidak maka solusi baru ditolak.

v. Lakukan penurunan suhu. Cek apakah $T<T$ akhir. Jika iya, proses Simulated Annealing dihentikan. Jika tidak, maka ulangi dari Langkah 6.k.i.

1. Menggabungkan seluruh solusi yang telah didapatkan.

m. Menentukan G-best yaitu calon solusi terbaik. Pada iterasi pertama, firefly terbaik menjadi G-best. Untuk iterasi lainnya, bandingkan firefly terbaik dengan $G$-best. Jika intensitas cahaya firefly terbaik lebih besar daripada intensitas cahaya G-best maka firefly tersebut akan menjadi G-best.

n. Update G-best sebagai calon solusi terbaik. 
o. Melakukan pergerakaan pada firefly terbaik. Setelah itu, hitung MSE dan intensitas cahaya firefly setelah melakukan pergerakan.

p. Cek apakah nilai MSE G-best yang diperoleh kurang dari maks_error atau maksimum iterasi (maks_iterasi) telah terpenuhi. Jika iya, proses dilanjutkan ke Langkah 6.q. Jika tidak, proses dilanjutkan ke Langkah 6.g.

q. Menyimpan hasil bobot.

7. Melakukan uji validasi data pelatihan menggunakan nilai bobot dan bias yang diperoleh dariproses pelatihan. Langkah-langkah uji validasi sebagai berikut:

a. Input data validasi yang akan diuji.

b. Menginisialisasi bobot dan bias optimal dalam JSTB. Inisialisasi ini didapatkan dari langkah 6.

c. Masukkan parameter yang digunakan pada proses pelatihan.

d. Lakukan proses feedforward dalam JSTB.

e. Menampilkan output dari proses feedforward.

Flowchart proses Jaringan Saraf Tiruan Backpropagation dengan Firefly Algorithm dan Simulated Annealing dapat dilihat pada Gambar 1.

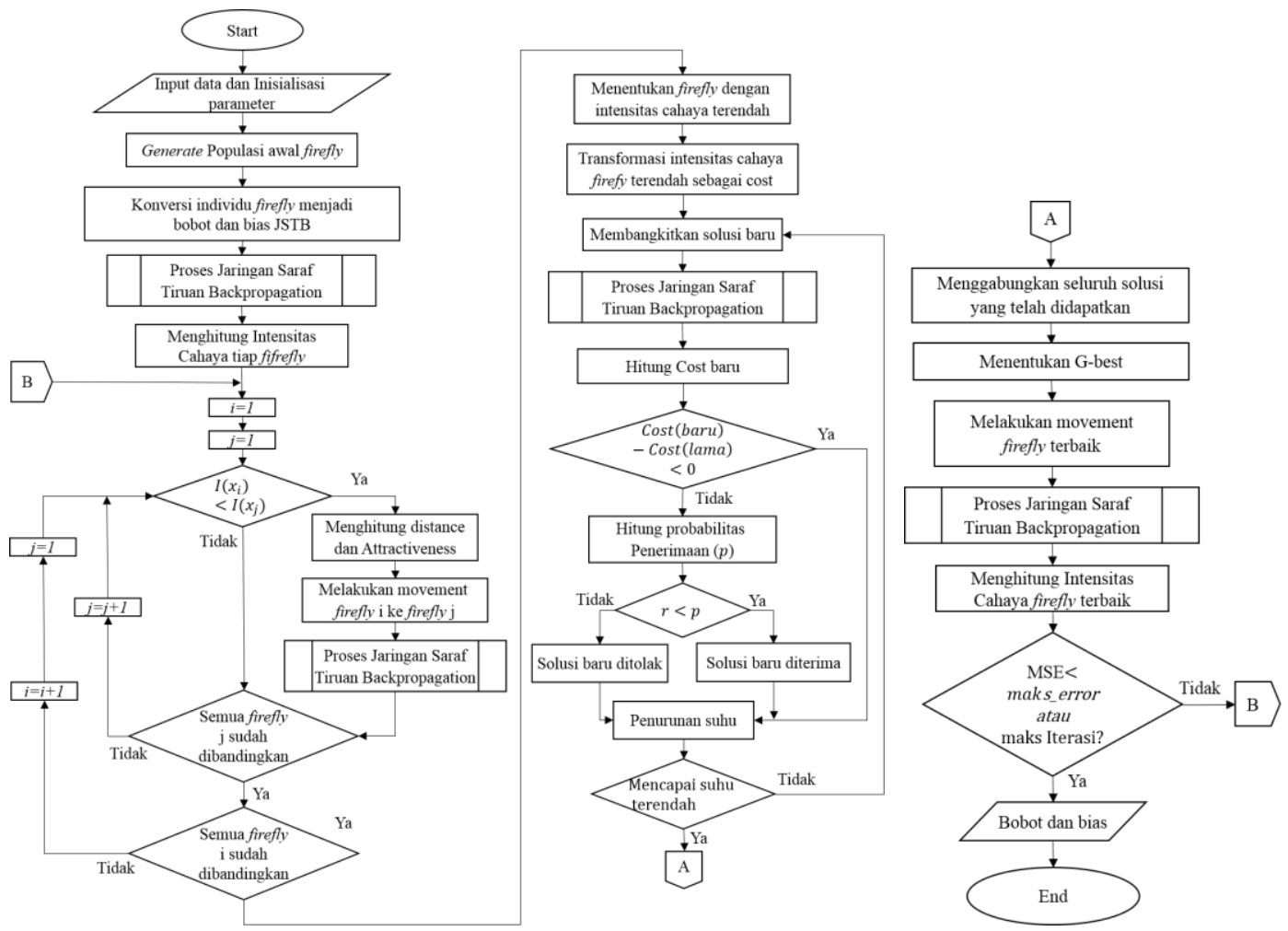

Gambar 1 Flowchart proses Jaringan Saraf Tiruan Backpropagation dengan Firefly Algorithm dan Simulated Annealing 
8. Melakukan denormalisasi data.

9. Mengimplementasikan program yang telah dibuat pada masalah peramalan curah hujan.

\section{$4 \quad$ Hasil dan Pembahasan}

Untuk menyelesaikan masalah peramalan curah hujan di kota Surabaya menggunakan Hybrid jaringan saraf tiruan Backpropagation dengan Firefly Algorithm dan Simulated Annealing telah dibuat program untuk membantu proses perhitungan menggunakan bahasa pemrogaman Java dengan bantuan software Netbeans IDE 8.0.2.

Proses awal pada program ini adalah pelatihan data. Pada proses pelatihan diawali dengan memasukkan nilai parameter-parameter yang dibutuhkan. Parameter tersebut antara lain adalah banyaknya firefly, batas error, maksimal iterasi, koefisien penyerapan udara, keatraktifan awal, koefisien random, suhuawal, suhu akhir, dan koefisien penurunan suhu. Nilai parameter yang digunakan pada pelatihan data ini yaitu maksimum iterasi $=10000$, batas error $=0.001$, nilai keatraktifan awal $=1$, suhu awal $=10000$, suhu akhir $=1$, dan koefisien penurunan suhu $=0.1$. Sedangkan banyaknya firefly, koefisien penyerapan udara, dan koefisien random merupakan parameter yang diubah-ubah. Setelah input parameter selesai, maka program akan menghasilkan bobot dan bias optimal dengan nilai MSE untuk masing-masing percobaan. Kemudiaan dipilih nilai MSE yang terkecil. Berikut hasil percobaan pelatihan dapat dilihat pada Tabel 2.

Berdasarkan Tabel 2, pada percobaan ke-18 diperoleh nilai MSE terkecil dari proses pelatihan adalah sebesar 0.0395384228 dengan dengan jumlah individu firefly yang digunakan adalah sebanyak 20, koefisien penyerapan udara $(\gamma)=1,5$, nilai keatraktifan awal $\left(\beta_{0}\right)=1$, dan nilai koefisien random $\alpha=0,8$. Nilai bobot dan bias terbaik dapat dilihat pda Tabel 3 dan Tabel 4 . Nilai bobot dan bias terbaik yang dihasilkan dari proses pelatihan, selanjutnya digunakan pada uji validasi.

Setelah proses pelatihan dilakukan, langkah selanjutnya adalah proses validasi terhadap data yangbelum pernah digunakan dalam proses pelatihan. Uji validasi ini dilakukan untuk melihat seberapa besar eror hasil peramalan curah hujan di kota Surabaya. Pada proses uji validasi dilakukan proses feedforward jaringan saraf tiruan menggunakan bobot dan bias terbaik yang diperoleh dari proses pelatihan. Setelah memperoleh nilai output atau hasil peramalan pada proses feedforward, selanjutnya dihitung hasil selisih eror yang dihasilkan. Hasil uji validasi dapat dilihat pada Tabel 5. 
Tabel 2 Hasil percobaan pelatihan data

\begin{tabular}{|c|c|c|c|c|}
\hline No. & firefly & $\begin{array}{c}\text { Koefisien } \\
\text { udara } \\
(\gamma)\end{array}$ & $\begin{array}{l}\text { Koefisien } \\
\text { random } \\
(\alpha)\end{array}$ & MSE \\
\hline 1 & \multirow{9}{*}{10} & \multirow{3}{*}{0.5} & 0.1 & 0.0400038357 \\
\hline 2 & & & 0.5 & 0.0419995020 \\
\hline 3 & & & 0.8 & 0.0419963027 \\
\hline 4 & & \multirow{3}{*}{1} & 0.1 & 0.0408890845 \\
\hline 5 & & & 0.5 & 0.0421927186 \\
\hline 6 & & & 0.8 & 0.0426184953 \\
\hline 7 & & \multirow{3}{*}{1.5} & 0.1 & 0.0416505263 \\
\hline 8 & & & 0.5 & 0.0427456853 \\
\hline 9 & & & 0.8 & 0.0412489815 \\
\hline 10 & \multirow{9}{*}{20} & \multirow{3}{*}{0.5} & 0.1 & 0.0407439307 \\
\hline 11 & & & 0.5 & 0.0415554002 \\
\hline 12 & & & 0.8 & 0.0436114638 \\
\hline 13 & & \multirow{3}{*}{1} & 0.1 & 0.0412850129 \\
\hline 14 & & & 0.5 & 0.0423823425 \\
\hline 15 & & & 0.8 & 0.0406383275 \\
\hline 16 & & \multirow{3}{*}{1.5} & 0.1 & 0.0417282268 \\
\hline 17 & & & 0.5 & 0.0425468934 \\
\hline 18 & & & 0.8 & 0.0395384228 \\
\hline 19 & \multirow{9}{*}{50} & \multirow{3}{*}{0.5} & 0.1 & 0.0406854723 \\
\hline 20 & & & 0.5 & 0.0422393247 \\
\hline 21 & & & 0.8 & 0.0429385087 \\
\hline 22 & & \multirow{3}{*}{1} & 0.1 & 0.0413094229 \\
\hline 23 & & & 0.5 & 0.0427697167 \\
\hline 24 & & & 0.8 & 0.0419941870 \\
\hline 25 & & \multirow{3}{*}{1.5} & 0.1 & 0.0420737806 \\
\hline 26 & & & 0.5 & 0.0416733926 \\
\hline 27 & & & 0.8 & 0.0406338550 \\
\hline
\end{tabular}


Tabel 3 Bobot dan bias terbaik dari input ke hidden

\begin{tabular}{|c|c|c|c|}
\cline { 2 - 4 } \multicolumn{1}{c|}{} & $\mathrm{h} 1$ & $\mathrm{~h} 2$ & $\mathrm{~h} 3$ \\
\hline $\mathrm{x} 1$ & -0.5929 & -0.8284 & -0.3976 \\
\hline $\mathrm{x} 2$ & -1.1577 & -0.5770 & -0.9172 \\
\hline $\mathrm{x} 3$ & -0.7693 & -1.1497 & -0.7742 \\
\hline $\mathrm{b} 1$ & -1.1722 & -0.7547 & -0.4571 \\
\hline
\end{tabular}

Tabel 4 Bobot dan bias terbaik dari hidden ke output

\begin{tabular}{|c|c|}
\cline { 2 - 2 } \multicolumn{1}{c|}{} & o1 \\
\hline h1 & -0.9679 \\
\hline h2 & -0.9298 \\
\hline h3 & -0.5955 \\
\hline b2 & -0.3268 \\
\hline
\end{tabular}

Tabel 5 Hasil uji validasi

\begin{tabular}{|c|c|c|c|}
\hline No & $\begin{array}{c}\text { Data } \\
\text { Aktual }\end{array}$ & $\begin{array}{c}\text { Hasil } \\
\text { Peramalan }\end{array}$ & $\begin{array}{c}\text { Selisih } \\
\text { Eror }\end{array}$ \\
\hline 1 & 6.92222 & 6.27962 & 0.6426 \\
\hline 2 & 14.52273 & 6.00431 & 8.51842 \\
\hline 3 & 4.97073 & 6.08599 & 1.11526 \\
\hline 4 & 2.81739 & 5.93822 & 3.12083 \\
\hline 5 & 2.36154 & 5.58203 & 3.22049 \\
\hline 6 & 4.19773 & 4.95321 & 0.75548 \\
\hline 7 & 7.90238 & 4.94887 & 2.95351 \\
\hline 8 & 7.33333 & 5.32369 & 2.00964 \\
\hline 9 & 14.56667 & 5.60126 & 8.96541 \\
\hline 10 & 17.83462 & 6.12963 & 11.70499 \\
\hline 11 & 12.05122 & 6.5675 & 5.48372 \\
\hline 12 & 9.90851 & 6.6472 & 3.26131 \\
\hline 13 & 5.53617 & 6.43234 & 0.89617 \\
\hline
\end{tabular}

Berdasarkan hasil uji validasi tersebut, diperoleh selisih eror rata-rata sebesar 3.75382 . Setelah proses uji validasi selesai, kemudian dilanjukan ke proses peramalan. Proses peramalan ini dilakukan untuk meramalkan curah hujan di kota Surabaya pada bulan berikutnya. Pada proses peramalan dilakukan proses feedforward jaringan saraf tiruan menggunakan bobotdan bias terbaik yang diperoleh dari proses pelatihan. Data yang 
digunakan adalah data 3 bulan terakhir yaitu bulan Oktober hingga Desember 2017. Data yang digunakan untuk peramalan dapat dilihat pada Tabel 6.

Hasil peramalan untuk 3 bulan berikutnya yaitu bulan Januari hingga Maret 2018 dapat dilihat pada Tabel7.

Tabel 6 Data untuk peramalan

\begin{tabular}{|c|c|}
\hline & $\begin{array}{c}\text { Rata-rata curah hujan } \\
(\mathrm{mm})\end{array}$ \\
\hline Okt-17 & 1.4929 \\
\hline Nov-17 & 11.6491 \\
\hline Des-17 & 9.7897 \\
\hline
\end{tabular}

Tabel 7 Hasil peramalan

\begin{tabular}{|c|c|c|c|c|}
\hline & $\mathrm{x} 1$ & $\mathrm{x} 2$ & $\mathrm{x} 3$ & Hasil Peramalan \\
\hline Jan-18 & 1.4929 & 11.6491 & 9.7897 & 6.1451 \\
\hline Feb-18 & 11.6491 & 9.7897 & 6.1451 & 8.5459 \\
\hline Mar-18 & 9.7897 & 6.1451 & 8.5459 & 7.7391 \\
\hline
\end{tabular}

\section{$5 \quad$ Kesimpulan}

Berdasarkan implementasi yang dilakukan pada data curah hujan di kota Surabaya diperoleh hasil MSE terbaik pelatihan sebesar 0.0395384228. Nilai MSE cukup kecil sehingga bobot optimal yang dihasilkan mampu mengenali pola data dengan baik. Pada uji validasi diperoleh rata-rata selisih eror sebesar 3.75382. Sedangkan hasil peramalan untuk 3 bulan berikutnya yaitu bulan Januari hingga Maret 2018 berturut-turut adalah 6.1451, $8.5459,7.7391$.

\section{Daftar Pustaka}

[1] Katarina, Tumiar M., 2014, Klimatologi Dasar : Unsur Iklim dan Proses Pembentukan Iklim, Penerbit Graha Ilmu, Yogyakarta.

[2] Kodoatie, Robert J., 2013, Rekayasa dan Manajemen Banjir Kota. Penerbit Andi, Yogyakarta.

[3] Fausett, L., 2003, Fundamental of Neural Network Architecture, Algorithm, and Application, Printice-Hall,Inc, London.

[4] Roosmalita, Nadia S., Wayan Firdaus M., Aji Prasetya W., 2016, Backpropagation on Neural Network Method for Inflation Rate Forecasting in Indonesia, International Journal Advance Soft ComputerApplications, Vol. 8 No. 3. 
[5] Frolic A., I.M., \& J, Bhuvana. 2014, May. Backpropagation Based Firefly Algorithm for CharacterRecognition. Chennai, India.

[6] Yang, X. S., 2010, Engineering Optimization: An Introduction with Metaheuristic Applications, Wiley \& Sons, Inc, New Jersey, USA.

[7] Krikpatrick, S., Gelatt, C. D. and Vecchi, M. P., 1983, Optimization by Simulated Annealing, Science, 220,671-680.

[8] Mohammad S.M., Elham S.M., Pengcheng Jiao, 2017, Next generation prediction model for daily solar radiation on horizontal surface using a hybrid neural network and simulated annealing method, Energy Conversion and Management 153 (2017) 671-682.

[9] Nandy, Suharshan, Partha P.S. dan Achintya D., 2012, Analysis of a Nature Inspired Firefly Algorithm based Back-propagation Neural Network Training, International Journal of Computer Applications (0975- 8887), Vol 43.

[10] Rachmawati, Kusratmoko E, Damayanti A., 2004, Peristiwa Banjir Tahun 1996 dan 2002 di Daerah Aliran Ciliwung. Makalah Semiloka Pengelolaan Tata Air \& Sampah Jakarta. 14 Agustus 2004. 